\title{
Valuing environmental quality in actual travel time savings - The Haningeleden road project in Stockholm
}

\author{
Pernilla Ivehammar
}

\section{Linköping University Post Print}

\section{Tweet}

N.B.: When citing this work, cite the original article.

Original Publication:

Pernilla Ivehammar, Valuing environmental quality in actual travel time savings - The Haningeleden road project in Stockholm, 2014, Research in Transportation Economics, (48), 349-356.

http://dx.doi.org/10.1016/j.retrec.2014.09.062

Copyright: Elsevier

http://www.elsevier.com/

Postprint available at: Linköping University Electronic Press

http://urn.kb.se/resolve?urn=urn:nbn:se:liu:diva-112579 


\title{
Valuing environmental quality in actual travel time savings - The Haningeleden road project in Stockholm
}

\author{
Pernilla Ivehammar \\ Department of Management and Engineering, Linköping University, Sweden \\ pernilla.ivehammar@liu.se
}

\begin{abstract}
Effects on the environment are rarely valued in planning infrastructure for different modes of transport. This can detract from optimal planning and fair competition, which might be better served by valuing environmental quality changes through actual travel time savings. New transport infrastructure often creates both positive and negative effects for the same groups of users, although to different degrees for different individuals. This paper illustrates a proposed methodology to investigate the effect of a planned transport infrastructure investment through a survey of potential users of the Haningeleden road project in Stockholm. Postal questionnaires were sent to a random sample of 2400 persons living in the affected area in May and June 2013, including detailed questions about their travel patterns and visiting frequencies, and whether, after reading a description of the proposed change, they would be in favour of the proposed change. The negative encroachment costs and the positive relief from traffic in other areas were estimated in travel time savings.
\end{abstract}

Keywords: Contingent valuation method; Cost benefit analysis; Encroachment cost; Environmental quality; Road investment; Transport infrastructure; Travel time savings; Valuation

\section{Introduction}

Some effects are rarely valued in planning transport infrastructure. This is a problem for optimal planning and fair competition between different modes of transport. To decide which transport infrastructure investments are socially desirable, all effects caused by different projects should be estimated (Boardman et al., 2010). One potentially important effect often missing is the encroachment of transport infrastructure and its traffic on valuable environments, such as nature areas used for recreational or other purposes. Such environmental quality effects should be included in the cost benefit analysis of infrastructure projects, but it is not clear how to value some of these effects. Without knowing the preferences of those affected, the infrastructure planner must make valuations arbitrarily, sometimes assigning limitless values and sometimes zero values to projected effects (Carson, 2012), possibly leading to wrong decisions.

One way to estimate effects is to determine people's willingness to pay for (WTP) or willingness to accept (WTA) the specific good or to avoid the specific bad (Bateman et al., 2002, Freeman, 2003). One frequently used 'stated preferences' method is the contingent valuation method (CVM) (Carson, 2000, Mitchell and Carson, 1989). In the CVM-variant dichotomous choice, first used by Bishop and Heberlein (1979), each respondent is asked about a specific bid to have the good or accept the bad. Debate over the usefulness of CVM continues (Haab, 2013, Hausman, 2012), and one problem with it is that the choice of hypothetical payment vehicle may affect the WTP (Ivehammar, 2009).

'Revealed preference' methods are based on the natural variance of some quantifiable effects, such as travel costs, among individuals - a principle that could also be used in studies based on stated preferences. New local or regional transport infrastructure often means both positive and negative effects for the same individuals. One common reason for a 
transport infrastructure investment is travel time savings, but while the new infrastructure may relieve traffic in other areas, it may also encroach on other areas such as those used for recreation. The travel time saved by the use of a new road that encroaches on a valuable environmental area naturally varies among individuals, depending on their individual travel patterns.

A random sample of individuals in a population can be asked a dichotomous-choice CVM question that uses their potential travel time savings with the new road (Ivehammar, 2008). Instead of a hypothetical bid, each respondent's bid is the actual amount of travel time that respondent would save, which is then used to estimate both the encroachment cost and the traffic relief in other areas. An advantage of the method is that it can be used ex ante when using hypothetical monetary bids might be sensitive. In Sweden, the method has been recommended when winners and losers belong to the same group (The Swedish Transport Administration, 2014). A road project in Stockholm (recently investigated, but not yet decided) was selected for this study to further develop and illustrate this method.

\section{The approach}

Suppose that a planned new road would encroach upon a local recreational area, while it would also relieve other areas from traffic and save time for travellers. Individuals living in the area, affected more or less by all three effects, are asked to state whether or not they want the road to be built. The analysis of their discrete choices is based upon random utility theory, developed by McFadden (1974) and described by Haab and McConnell (2003). If environmental quality at the recreational area is $\mathrm{EE}$, environmental quality at the area relived from traffic is ER, leisure time is $t$, and income is $M$, the choice can be described as:

$$
\begin{aligned}
& U_{k}\left(M, E E_{1}, E R_{1}, t_{1}\right) \geq U_{k}\left(M, E E_{0}, E R_{0}, t_{0}\right) \rightarrow \text { yes-answer } \\
& U_{k}\left(M, E E_{1}, E R_{1}, t_{1}\right)<U_{k}\left(M, E E_{0}, E R_{0}, t_{0}\right) \rightarrow \text { no-answer }
\end{aligned}
$$

where $U_{k}$ is the indirect utility function for individual $k, E_{1}$ is the (lower) environmental quality in the recreational area if the road is built, $\mathrm{ER}_{1}$ is the (higher) environmental quality in the relieved area if the road is built, and $t_{1}$ is the (increased) leisure time available because of decreased travel time if the road is built. $\mathrm{EE}_{0}, \mathrm{ER}_{0}$, and $\mathrm{t}_{0}$ represent those values without the new road. Real income, $M$, is unchanged because it is assumed that no substantial expenses would be affected by this minor project, that the expense of building the road will be shared between all members of the national population, and that this minor national budget effect will be ignored by the individual. The new road may lower costs for fuel and vehicle maintenance through savings in travel time. Income might therefore be somewhat increased by those decreased fuel and maintenance costs and also changed indirectly by changed behaviours due to the new road. Fuel and maintenance cost savings might be included with the savings in travel time as some set amount per minute.

Because individuals all have different travel patterns - based on residence, place of work, habit, and other factors - their saved travel times with the new road would also differ, as would the effects on them of traffic relief in some areas and encroachments on the environmental area. All other things being equal, people should favour the new road if they believe their individual savings in travel time (and fuel and vehicle maintenance) and the traffic relief elsewhere would compensate for the road's detrimental effect on the recreational area.

In this method, a random sample of individuals is drawn from the affected population and first 
asked to answer detailed questions regarding their travel habits and how often they visit specific areas. After being informed about the planned new road and its effects, the respondents are asked to estimate how often they would travel on the new road and how much time they think they would save. While thinking about the effects of the new road, respondents are asked whether or not they want the new road to be built and their reasons for the choice. Socio-economic data are also collected and the individual choices are analysed in light of the road's different anticipated effects for each individual.

It is important to capture as accurately as possible the travel time saved with the new road. Respondents' estimates are best to use for this, provided that they answer the question correctly. A question about how often they think they would travel the new road were it built should also be included to allow travel time savings to be assigned to respondents not answering the exact question.

A problem is that respondents may be influenced in their answers by conscious or unconscious biases. Status quo bias (a wish for constancy and resistance to change) has been reported for other stated preferences methods (Beenstock et al., 1998, Hartman et al., 1990, Ortona and Scacciati, 2003) and may be revealed by an ex ante study and an ex post study of the same change. Another possible bias (strategic answering) can arise when respondents already have a preference about the new road. Those who have already decided that they do not want the new road might say that they would save no travel time at all, while those who are predisposed in favour of the new road might overestimate their travel time savings. One way to check for this is to compare stated travel time savings with answers to questions about present travel patterns. In an earlier study using this method (Ivehammar, 2008), respondents' estimated travel time savings correlated well with the same respondents' present travel patterns. Very few respondents offered estimates of travel time savings that could be seen as strategically motivated.

Utility can be supposed to consist of a deterministic part and a random part (the error term). If the utility function is assumed to be linear and the error terms are independently and identically distributed with a mean of zero, the net of the indirect utility function can be described as

$$
\begin{aligned}
& U_{n e t, k}=V_{k}+\varepsilon_{k} \\
& V_{k}=\alpha+\beta_{\text {time }} \text { time }_{k}+\sum_{i} \chi_{i} X_{i k}+\sum_{i} \eta_{i} Z_{i k}+\sum_{j} \delta_{j} Y_{j k}
\end{aligned}
$$

where $U_{\text {net, } \mathrm{k}}$ is the net utility for individual $\mathrm{k}$ of having, rather than not having, the road, and $\mathrm{V}_{\mathrm{k}}$ is the deterministic part. The variable time $\mathrm{k}_{\mathrm{k}}$, is the travel time saved by individual $\mathrm{k}$ if the road exists, $X_{i k}$ are variables describing the exposure in the recreational area, $Z_{i k}$ are variables describing the exposure in the relieved area, $Y_{j k}$ are socio-economic variables, and $\varepsilon_{\mathrm{k}}$ is the random term. $X_{\mathrm{ik}}$, which could represent visiting frequencies in the recreational area before the new road, aims to capture the $\Delta E E$ for individual $\mathrm{k}$ were the road to be built. Similarly, $Z_{i k}$, which could represent current visiting frequencies in the area that would be relieved by the new road, aims to catch $\triangle E R$ for individual $k$ were the road to be built. If socio-economic variables were included, these variables could be integrated with the other terms in different ways.

A logit model (Louviere et al., 2006) may be applied to analyse the results. The parameters can be interpreted as ratios (Hanemann, 1989). Excluding socio-economic variables, the average willingness to substitute (WTS) travel time for the environmental encroachment can be calculated as: 


$$
E[W T S]=\frac{1}{-\beta_{\text {time }}}\left(\alpha+\sum \chi_{i} \bar{X}_{i}\right)
$$

where a may catch values of the environmental area not dependent on visiting frequencies (existence values) and average values for $X_{i}$ are used. The average willingness to substitute travel time for the traffic relief in another area can be calculated as:

$$
E[W T S]=\frac{1}{\beta_{\text {time }}}\left(\sum \eta_{i} \bar{Z}_{i}\right)
$$

where average values for $Z_{i}$ are used. It is assumed that the relieved area is not unique and does not have any existence values. If both the area encroached upon and the area relieved from traffic are thought to be unique and to possibly have existence values, the interpretation of a might be more difficult.

The estimated values of the effects on environmental quality will be expressed in travel time savings. Socio-economic variables may also be included in (3) and (4) to find different values for different categories in the population and travel time savings may also include decreased costs for fuel and vehicle maintenance. The estimated coefficient for travel time would then be a measure of both the saved travel time and some proportional vehicle operational cost savings per minute. One way to translate WTS into monetary terms is to use standardized units for travel time.

\section{The study of the road project Haningeleden in Huddinge municipality in Stockholm}

The approach to valuing environmental encroachments and traffic relief caused by transport infrastructure in actual travel time savings described in Section 2 was applied to a road project recently investigated, but not decided, by the Swedish Transport Administration. The description of the new road and its effects was written in cooperation with the Swedish Transport Administration and the concerned local authorities.

The proposed new road, called Haningeleden, aims to relieve traffic in some areas of the Huddinge municipality (population around 100 000; Statistics Sweden, 2013) in Stockholm, increase mobility in the area, and save travel time (and vehicle operating costs) on trips between the northern and southern parts of the town. The problem is that it would pass through environmental areas used for recreation and encroach upon some housing areas.

After designing the questionnaire with the help of focus groups and a pilot study in the population in April 2013, 2400 postal questionnaires were mailed to a sample of inhabitants, 18 years and older, of the municipality of Huddinge. A random sample of 1500 persons from the whole municipality, was used. Because some individuals in the municipality live far away from the new road and might not be much affected by the road project, two samples from areas more affected by the new road were added to this study. All 470 people 18 years and older living in one area were sent a questionnaire, as were a random sample of 495 (500 with 5 excluded as underage) of the 2550 people aged 18 years and older in another area. The map in the Appendix shows the sample areas. The main study, including two reminders, was carried out in May and June of 2013.

The questionnaire first asked a number of detailed questions about visiting frequencies in specific areas and travel behaviours on specific roads. The planned new road and its effects were then described with a map illustrating the route. Respondents were told that one single 
trip by car or other motor vehicle between two particular areas would be 4 kilometres shorter and save approximately 6 minutes travel time with the new road. The map from the questionnaire, where the new road is drawn in red, is shown in Figure 1.

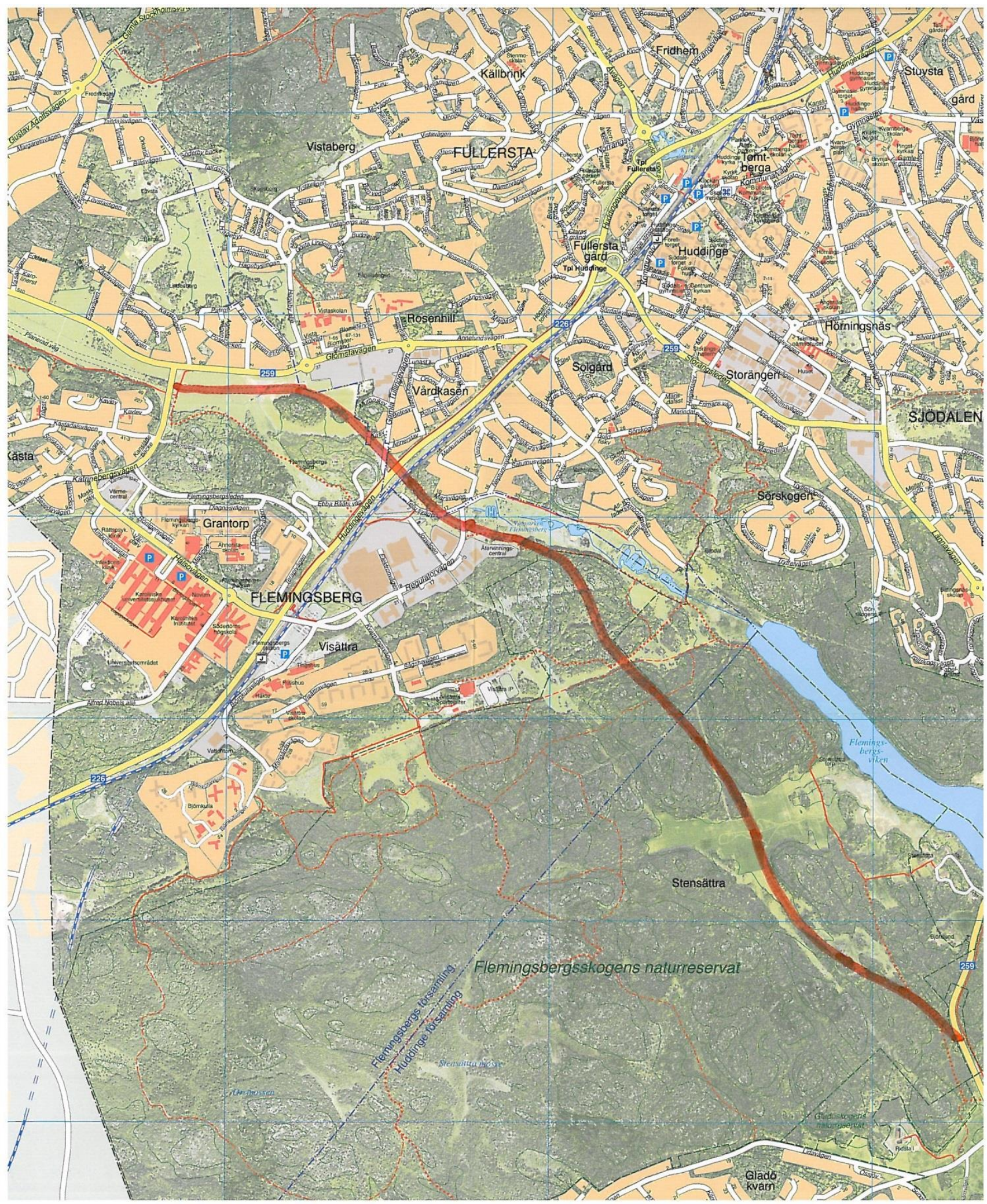

Figure 1. The map included in the questionnaire, Haningeleden marked in red 
The respondents were then asked how often they believed they would travel the new road and how much travel time they thought they would save, and whether and why they would want Haningeleden to be built. Final questions about gender, age, driving licence, vehicle access, place of residence, usual weekday location, household composition, household income, and free comments completed the questionnaire.

The environmental quality of Huddinge would be changed both positively and negatively by construction of the new road. Individual incomes would remain unchanged, since the Swedish Transport Administration would finance the construction and the national budget effect would be minor for each respondent. Savings in travel time would reduce costs for fuel and vehicle maintenance, although these cost reductions were not specifically pointed out in the questionnaire. If the benefits of the new road (traffic relief in some parts of Huddinge and saved travel time including vehicle operational costs savings) are estimated to balance or outweigh the costs (detrimental environmental encroachment), a respondent should want the new road. Different travel patterns and visiting frequencies in different areas mean that the new road would affect different respondents differently.

Respondents were asked about visiting frequencies in different parts of the encroached area as well as the area relieved from traffic. Table 1 shows the answering alternatives to those questions and the number of visiting days per week that would be assumed when choosing a specific alternative.

\section{Table 1. Visiting frequencies}

\begin{tabular}{|l|l|}
\hline Answering alternatives visiting frequency & Number of days per week visiting \\
\hline Every day & 7 \\
\hline 6 days per week & 6 \\
\hline 5 days per week & 5 \\
\hline 4 days per week & 4 \\
\hline 3 days per week & 3 \\
\hline 2 days per week & 2 \\
\hline 1 day per week & 1 \\
\hline 3-4 days per month & 0.9 \\
\hline 1-2 days per month & 0.4 \\
\hline -10 days per year & 0.2 \\
\hline 4-6 days per year & 0.1 \\
\hline -3 days per year & 0.05 \\
\hline Less than 2-3 days per year & 0.01 \\
\hline Never & 0 \\
\hline
\end{tabular}

The visiting frequencies in Table 1, as well as grouped visiting frequencies, can be used together with the saved travel time and other variables to explain the choice of wanting the new road or not.

\section{Results}

The response rate to the questionnaire was $51 \%$ overall, but in the sample from the subpopulation most affected by the new road it was $64 \%$. Some respondents did not answer the question about whether or not they wanted the Haningeleden road. The response rate to all essential questions, including the question about wanting the road or not, was $47 \%$.

Table 2 shows the response rates, defined as answering all essential questions, and the share of the respondents in the different samples who wanted Haningeleden to be built. 
Table 2. Sample size, response rate, and share wanting the Haningeleden road

\begin{tabular}{|l|l|l|l|l|l|}
\hline Sample & Sample size & $\begin{array}{l}\text { Revised } \\
\text { sample size }\end{array}$ & $\begin{array}{l}\text { Number of } \\
\text { answers }\end{array}$ & $\begin{array}{l}\text { Response } \\
\text { rate }\end{array}$ & $\begin{array}{l}\text { Share } \\
\text { wanting } \\
\text { Haningeleden }\end{array}$ \\
\hline $\begin{array}{l}\text { Haninge } \\
\text { municipality }\end{array}$ & $1500(1478)$ & $1470(1448)$ & $609(604)$ & $42 \%$ & $58 \%$ \\
\hline Gladö kvarn & $470(462)$ & $466(458)$ & $222(220)$ & $48 \%$ & $75 \%$ \\
\hline $\begin{array}{l}\text { Solgård } \\
\text { Sörskogen }\end{array}$ & $495(481)$ & $491(477)$ & $295(292)$ & $61 \%$ & $67 \%$ \\
\hline Total & 2443 & 2405 & 1121 & $47 \%$ & \\
\hline
\end{tabular}

22 people were randomly included in two samples and only completed one questionnaire, which explains the difference between the numbers in parentheses and the total number of answers being less than the sum of answers in each sample.

A larger share of the respondents in the subpopulations more affected by the new road than in the sample from the whole municipality wanted Haningeleden. In the larger population, some people would be hardly affected by the new road, and as expected, the response rate in this sample was lower.

The respondents were asked how much travel time per week they thought they would save with Haningeleden. 709 of the 1121 respondents answering all other important questions did state a precise saving in travel time. All but one of those also answered the question about how often they thought they would travel on the new road if it were built. Table 3 shows mean and median travel time savings stated by respondents answering both the question about how often they estimated they would travel the new road and the question about how many minutes they would save per week with the new road.

\section{Table 3. Travel frequency and saved travel time}

\begin{tabular}{|l|l|l|}
\hline $\begin{array}{l}\text { Frequency of travelling the } \\
\text { new road }\end{array}$ & $\begin{array}{l}\text { Mean of stated } \\
\text { travel time saving } \\
\text { minutes per week }\end{array}$ & $\begin{array}{l}\text { Median of stated } \\
\text { travel time saving } \\
\text { minutes per week }\end{array}$ \\
\hline Every day & 78 & 60 \\
\hline 6 days per week & 58 & 60 \\
\hline 5 days per week & 52 & 50 \\
\hline 4 days per week & 40 & 30 \\
\hline 3 days per week & 26 & 30 \\
\hline 2 days per week & 18 & 20 \\
\hline 1 day per week & 13 & 11 \\
\hline 3-4 days per month & 18 & 10 \\
\hline 1-2 days per month & 8 & 3 \\
\hline 7-10 days per year & 4 & 1 \\
\hline 4-6 days per year & 1 & 0 \\
\hline 2-3 days per year & 2 & 0 \\
\hline Less than 2-3 days per year & 3 & 0 \\
\hline Never & 1 & 0 \\
\hline
\end{tabular}

Because the mean would be affected by extreme values, the median for each travel pattern may be a more useful way to assign travel time savings to those not stating a specific amount of saved travel time. 401 of the 412 respondents not stating a travel time saving did answer the question about how often they thought they would travel on Haningeleden if it were built. They are assigned the median travel savings in Table 3 according to their stated frequency of travelling the new road. 
The response alternatives to the question about how often the respondents thought they would travel the new road were number of days per week, month, or year. An alternative could be to ask about the number of trips in some specific time period. The reason for choosing number of days was to avoid confusion by the respondent between single trips and return trips. This question was used only to assign travel time savings to respondents not answering the question about exact travel time saving per week.

The value of the change in environmental quality (positive in areas relieved from traffic and negative where the new road would cause environmental encroachment) is estimated as described in Section 2, equations (1)-(4), using a logit model. The relieved areas are not regarded as unique environments, but the environmental area encroached upon might have some existence values. Therefore the intercept is interpreted as possible existence values in the environmental area encroached upon.

A model is estimated after testing a large number of different explanatory variables to capture the effects on environmental quality. Dummy variables for the different subsamples are not significant when included in the chosen model. This model is one attempt (of a number of possible alternatives) to estimate the effects on environmental quality caused by Haningeleden to illustrate this methodological approach. All responses are used in the analysis. Data could alternatively be analysed only using respondents affected by some or all effects caused by the new road. Visiting frequencies in affected areas were used to capture both positive and negative effects on environmental quality, and an intercept was included to capture possible existence values in the environmental area encroached upon by the road. No socio-economic variables were included in this example to illustrate the approach as simply as possible. The estimated coefficients of the model are shown in Table 4.

Table 4. Estimated logit model, probability of wanting Haningeleden

\begin{tabular}{|l|l|l|l|l|l|}
\hline Variable & \multicolumn{2}{|l|}{ Coefficient } & Standard error & t statistic & $\mathrm{P}[|\mathrm{Z}|>\mathrm{z}]$ \\
\hline Intercept & $\alpha$ & 0.03225765 & 0.10029190 & 0.322 & 0.7477 \\
\hline $\begin{array}{l}\text { Saved travel time } \\
\text { minutes per week }\end{array}$ & $\beta_{\text {time }}$ & 0.04803441 & 0.00559172 & 8.590 & 0.0000 \\
\hline $\begin{array}{l}\text { Visiting Flemingsberg } \\
\text { wetlands every week }\end{array}$ & $\chi_{1}$ & -1.19990637 & 0.28540155 & -4.204 & 0.0000 \\
\hline $\begin{array}{l}\text { Visiting Flemingsberg } \\
\text { wetlands less than every } \\
\text { week but at least every half } \\
\text { year }\end{array}$ & $\chi_{2}$ & -0.45105460 & 0.21656789 & -2.083 & 0.0373 \\
\hline $\begin{array}{l}\text { Visiting Stensättra meadows } \\
\text { every week }\end{array}$ & $\chi_{3}$ & -1.57580770 & 0.41968824 & -3.755 & 0.0002 \\
\hline $\begin{array}{l}\text { Visiting Stensättra meadows } \\
\text { less than every week but at } \\
\text { least every half year }\end{array}$ & $\chi_{4}$ & -0.47123470 & 0.21750937 & -2.167 & 0.0303 \\
\hline $\begin{array}{l}\text { Visiting the area along } \\
\text { Storängsleden every week }\end{array}$ & $\eta_{1}$ & 0.79002185 & 0.21292135 & 3.710 & 0.0002 \\
\hline $\begin{array}{l}\text { Visiting the area along } \\
\text { Storängsleden less than } \\
\text { every week but at least every } \\
\text { half year }\end{array}$ & $\eta_{2}$ & 0.78707307 & 0.20137523 & 3.908 & 0.0001 \\
\hline $\begin{array}{l}\text { Days per week visiting the } \\
\text { area along Lännavägen }\end{array}$ & $\eta_{3}$ & 0.09050708 & 0.04778289 & 1.894 & 0.0582 \\
\hline $\mathrm{n}=1096$, Pseudo R2 $=0.16$, Percent correct predicted =69 & & \\
\hline
\end{tabular}


Flemingsberg wetlands and Stensättra meadows are environmental areas that would be encroached upon by the planned new road, while the areas along Storängsleden and Lännavägen are areas that would be relieved from traffic. As expected, larger anticipated savings in travel time and higher visiting frequencies to the traffic-relieved areas increased the probability of wanting Haningeleden, while more frequent visits to the environmental areas encroached upon by Haningeleden decreased the probability of wanting the new road. The intercept is not significant; implying no existence values of the environmental area encroached upon by the inhabitants in Huddinge municipality. Table 5 shows the average of the used explanatory variables among the respondents in the random sample from the population of Huddinge municipality.

Table 5. Frequencies of the explanatory variables in the sample from Huddinge municipality

\begin{tabular}{|l|l|}
\hline Variable & Value of variable \\
\hline Visiting Flemingberg wetlands every week $\left(\bar{X}_{1}\right)$ & 0.0788 \\
\hline $\begin{array}{l}\text { Visiting Flemingberg wetlands more rarely than every } \\
\text { week but at least every half year }\left(\bar{X}_{2}\right)\end{array}$ & 0.1675 \\
\hline Visiting Stensättra meadows every week $\left(\bar{X}_{3}\right)$ & 0.0329 \\
\hline $\begin{array}{l}\text { Visiting Stensättra meadows less than every week but at } \\
\text { least every half year }\left(\bar{X}_{4}\right)\end{array}$ & 0.1367 \\
\hline Visiting the area along Storängsleden every week $\left(\bar{Z}_{1}\right)$ & 0.1306 \\
\hline $\begin{array}{l}\text { Visiting the area along Storängsleden less than every } \\
\text { week but at least every half year }\left(\bar{Z}_{2}\right)\end{array}$ & 0.1752 \\
\hline Visiting the area along Lännavägen, days per week $\left(\bar{Z}_{3}\right)$ & 0.6320 \\
\hline Saved travel time, minutes per week (average) & 10.28 \\
\hline
\end{tabular}

The average values of positive and negative environmental effects are estimated from the figures in Table 4 and Table 5. These effects, and the travel time saved, all expressed in travel time in minutes per year per person, are presented in Table 6.

Table 6. Estimated valuation in minutes per year for an average person

\begin{tabular}{|l|l|}
\hline Environmental encroachment & 310 minutes \\
\hline Traffic relief in parts of Huddinge & 323 minutes \\
\hline Time saving & 535 minutes \\
\hline
\end{tabular}

Table 6 shows that aside from large travel time savings with the new road, there would also be large environmental quality effects, both negative and positive. Saved fuel costs and vehicle maintenance costs with the new road would be proportional to the travel time savings, and all three effects would be proportionally larger if proportional vehicle operating costs were added to the time savings.

As mentioned earlier, dummy variables included in the applied model were tested and found not to be significant. Grouped, rather than continuous, variables for visiting frequencies, however, may have resulted in a somewhat overestimated valuation of the environmental qualities in Table 6 , since the mean visiting frequencies among the respondents in the sample from the municipality as a whole are approximately $11 \%$ lower than when the two specially affected samples are included.

Table 7 shows the magnitudes of the different effects if the value for travel time savings used by the Swedish Transport Administration (2014) for regional private trips by car, 6.6 euro per 
hour, is used to translate the estimated effects in monetary terms. ${ }^{1}$ First this is calculated for an average person with the respondents in the sample assumed to be representative of the population. The population of Huddinge includes 76131 persons 18 years or older (Statistics Sweden, 2013). Values are calculated per year, assuming that the estimated values for an average respondent are valid for all persons 18 years or older in the population. As an alternative, values are also calculated only for the random sample from the whole population answering the questionnaire ( $42 \%$ ), assuming that the other $58 \%$ of the population is not affected by the road. Total discounted values were calculated over 40 years using the discount rate of $3.5 \%$, as used by the Swedish Transport Administration (2014) for roads.

Table 7. Estimated effects in euro

\begin{tabular}{|l|l|l|l|}
\hline & $\begin{array}{l}\text { Environmental } \\
\text { encroachment }\end{array}$ & $\begin{array}{l}\text { Traffic relief in } \\
\text { parts of Huddinge }\end{array}$ & Time savings \\
\hline $\begin{array}{l}\text { Per person in the } \\
\text { sample }\end{array}$ & EUR 34.10 & EUR 35.53 & EUR 58.85 \\
\hline $\begin{array}{l}\text { For one year (if } \\
\text { respondents are } \\
\text { representative of the } \\
\text { population) }\end{array}$ & EUR 2 600 000 & EUR 2 700 000 & EUR 4 500 000 \\
\hline $\begin{array}{l}\text { For one year (if share } \\
\text { answering is share } \\
\text { affected) }\end{array}$ & EUR 1 100 000 & EUR 1 100000 & EUR 1900000 \\
\hline $\begin{array}{l}\text { Total over 40 years, with } \\
3.5 \% \text { discount rate (if } \\
\text { respondents are } \\
\text { representative of the } \\
\text { population) }\end{array}$ & EUR 55 400 000 & EUR 57 800000 & EUR 95700000 \\
\hline $\begin{array}{l}\text { Total over 40 years with } \\
3.5 \% \text { discount rate (if } \\
\text { share answering is } \\
\text { share affected) }\end{array}$ & EUR 23 300 000 & EUR 24 300 000 & EUR 40200000 \\
\hline
\end{tabular}

The figures in Table 7 have been rounded off. If vehicle operating costs were included all figures in Table 7 would be increased by some percentage.

\section{Concluding remarks}

A strength of this method to value environmental quality in actual travel time savings is that it allows the use of ex ante studies without having to use hypothetical payment vehicles and hypothetical bids, which may both be upsetting and unethical. The method is especially useful for estimating environmental use values, although it needs further development and testing for possible biases, such as status quo bias and strategic response behaviours. To study status quo bias, the same infrastructure object could be studied using the method both before and after implementation. Strategic response behaviours could be studied by comparing stated travel time savings with answers about current travel patterns and the respondent's residence and work place. It would also be interesting to conduct a split-sample study in which half of the sample were informed that the new road would save some vehicle operational costs together with the travel time savings, while the other half of the sample would not.

\footnotetext{
${ }^{1} 59$ Swedish kronor (SEK), 1 EUR $=8.9$ SEK at time of writing.
} 
Although most ( $58 \%$ ) of the respondents in the random sample from the municipality of Huddinge were in favour of Haningeleden, and positive effects for the inhabitants in Huddinge municipality seemed to be larger than negative effects, the road would still have a considerable negative encroachment effect on the environment. If the total benefits of the road project exceed the total costs, it may still be interesting to compare the estimated environmental encroachment cost with the extra cost of ameliorating measures, such as building part of the new road underground.

\section{Acknowledgements}

I am grateful for valuable comments from Thomas Sonesson, Linnea Ingebrand, Stefan Grudemo, two anonymous referees, and participants at the Thredbo 13 Workshop 6 'Delivering Sustainable Public Transport'. 


\section{References}

Bateman, I., Carson, R. T., Day, B., Hanemann, M., Hanley, N., Hett, T., Jones-Lee, M., Loomes, G., Mourato, S., Ozdemirouglu, E., Pearce, D. W., Sugden, R., Swanson, J. (2002) Economic valuation with stated preferences techniques: A manual. Cheltenham: Edward Elgar.

Beenstock, M., Goldin, E., Haitovsky, Y. (1998). Response bias in a conjoint analysis of power outages. Energy Economics, 20, 135-156.

Bishop, R. C., Heberlein, T. A. (1979). Measuring values of extramarket goods: Are indirect measures biased? American Journal of Agricultural Economics, 61, 926-930.

Boardman, A. E., Greenberg, D. G., Vining, A. R., Weimer, D. L. (2010) Cost-benefit analysis, concepts and practice, Fourth edition, Pearson Prentice Hall

Carson, R.T. (2000). Contingent Valuation: A User's Guide. Environmental Science \& Technology, 34, 1413-1418.

Carson, R.T. (2012). Contingent valuation: A practical alternative when prices aren't available. Journal of Economic Perspectives, 26 (4), 27-42.

Freeman, M. A. (2003). The measurement of environmental and resource values: Theory and Methods. Washington DC: Resources for the Future.

Haab, T. (2013). From hopeless to curious? Thoughts on Hausman's dubious to hopeless critique of contingent valuation. Applied Economics Perspectives and Policy, 35, 593-612.

Haab, T. C., McConnell, K. E. (2003). Valuing environmental and natural resources. The econometrics of non-market valuation. Cheltenham: Edward Elgar.

Hanemann, M. W. (1989). Welfare evaluations in contingent valuation experiments with discrete responses: Reply. American Journal of Agricultural Economics, 71, 1057-1061.

Hartman, R. S., Doane, M. J., Woo, C-K. (1990). Status quo bias in the measurement of value of service. Resources and Energy, 12, 197-214.

Hausman, J. (2012). Contingent valuation: From dubious to hopeless. Journal of Economics Perspectives, 26 (4), 43-56.

Ivehammar, P. (2008). Valuing in actual travel time environmental encroachment caused by transport infrastructure. Transportation Research, Part D 13, 455-461.

Ivehammar, P. (2009). The payment vehicle used in CV studies of environmental goods does matter. Journal of Agricultural and Resource Economics, 34, 450-463.

Louviere, J. J., Hensher, D. A., Swait, J. D. (2006). Stated choice methods. Analysis and application. Cambridge: Cambridge University Press.

McFadden, D. (1974). Conditional logit analysis of qualitative choice behavior. In P. Zarembka (Ed.), Frontiers in Econometrics (105-142). New York: Academic Press.

Mitchell, R. C., Carson, R. T. (1989). Using surveys to value public goods: The contingent valuation method. Washington DC: Resources for the Future. 
Ortona, G., Scacciati, F. (2003). Endowment effect, status quo bias and contingent valuation. Rivista Internazionale di Scienze Sociali, 111, 398-407.

Statistics Sweden (SCB). (2013). www.scb.se

The Swedish Transport Administration. (2014). Samhällsekonomiska principer och kalkylvärden för transportsektorn: ASEK 5.1. http://www.trafikverket.se/Foretag/Planera-ochutreda/Planerings--och-analysmetoder/Samhallsekonomisk-analys-och-

trafikanalys/Modellanpassade-indata--och-omvarldsforutsattningar/ 


\section{Appendix}

\section{Huddinge kommun}

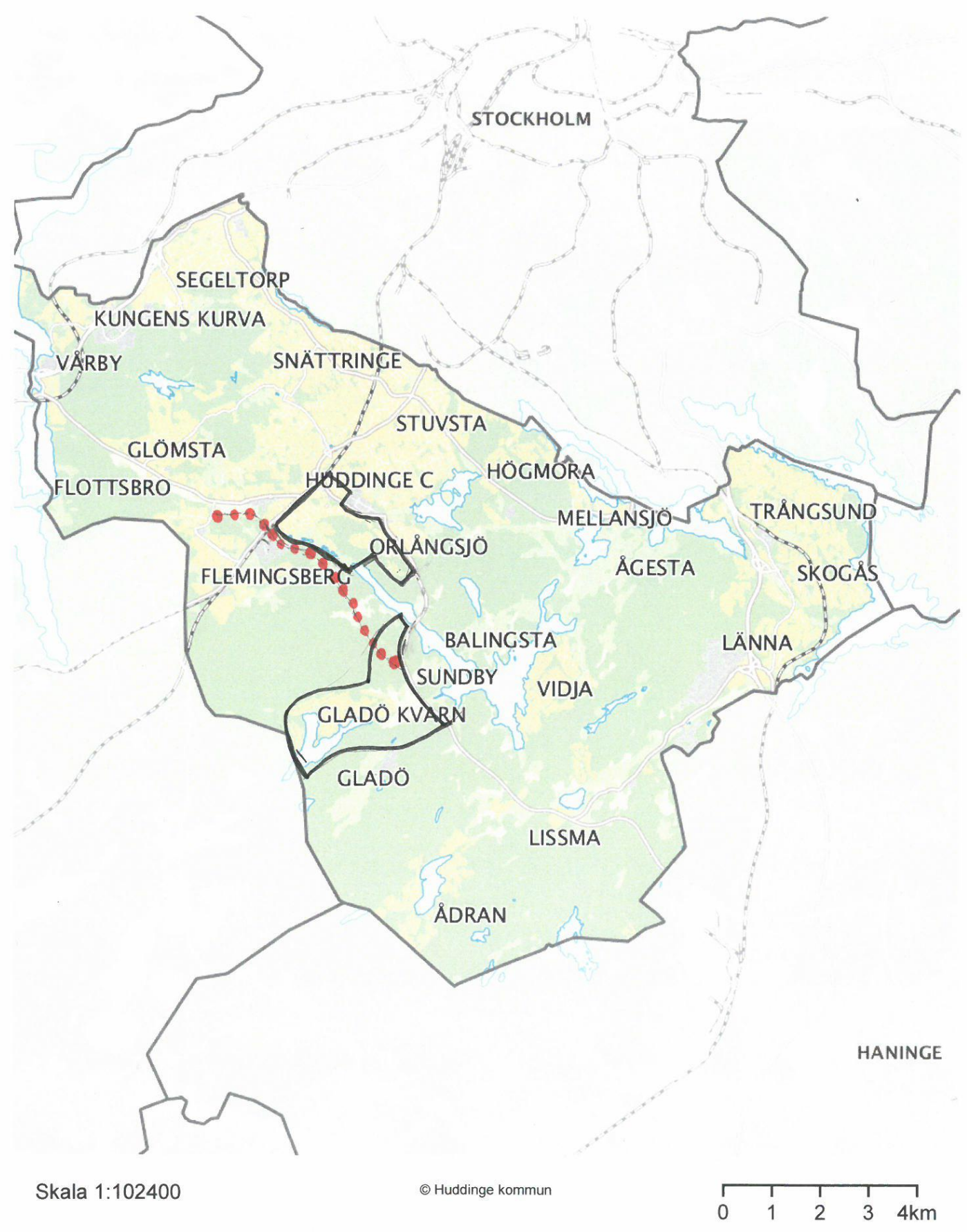

